\title{
REVIEW
}

\section{The role of higher protein diets in weight control and obesity-related comorbidities}

\author{
A Astrup ${ }^{1}$, A Raben $^{1}$ and N Geiker ${ }^{2}$
}

The importance of the relative dietary content of protein, carbohydrate and the type of carbohydrate (that is, glycemic index (GI)) for weight control under ad libitum conditions has been controversial owing to the lack of large scale studies with high diet adherence. The Diet, Obesity and Genes (DioGenes) European multicentre trial examined the importance of a slight increase in dietary protein content, reduction in carbohydrate and the importance of choosing low (LGl) vs high Gl (HGl) carbohydrates for weight control in 932 obese families. Only the adults underwent a diet of 800 kcal per day for 8 weeks, and after losing $\sim 11 \mathrm{~kg}$ they were randomized to one of five energy ad libitum diets for 6 months. The diets differed in protein content and Gl. The high-protein (HP) diet groups consumed 5.4\% points more energy from protein than the normal protein (NP) groups, and the LGI diet groups achieved $5.1 \%$ lower Gl than the HGI groups. The effect of HP and LGI was additive on weight loss and maintenance, and the combination was successful in preventing weight regain and reducing drop-out rate among the adults after the $11 \mathrm{~kg}$ weight loss. This diet also reduced body fatness and prevalence of overweight and obesity among their children and had consistent beneficial effects on blood pressure, blood lipids and inflammation in both parents and children. After 1 year, mainly the HP effects were maintained. Putative genes have been identified that suggest this diet to be particularly effective in $67 \%$ of the population. In conclusion, the DioGenes diet has shown to be effective for prevention of weight regain and for weight reduction in overweight children under ad libitum conditions. The less-restrictive dietary approach fits into a normal food culture, and has been translated into popular diet and cook books in several languages.

International Journal of Obesity (2015) 39, 721-726; doi:10.1038/ijo.2014.216

The level of protein in the diet normally recommended is determined by the minimum daily intake required to maintain nitrogen balance; that is, enough protein of a sufficiently high quality to prevent the catabolism of own protein stores. This is a major issue, particularly given the increased prevalence of sarcopenia in the elderly population. ${ }^{1}$ However, prevention of autodigestion might not be the same as optimal health, and the concept that higher levels of dietary protein could help prevent and treat disorders, such as obesity, metabolic syndrome, type 2 diabetes (T2D) and atherosclerotic cardiovascular disease, is gaining increasing support. This narrative review with emphasis on the DioGenes study aims to present the evidence supporting the recommendation of higher protein diets for management of obesity and T2D, and addresses the associated changes in cardiovascular risk factors. Although focus will be on higher protein diets providing $20-30 \%$ of the diet's energy, diets with higher protein contents, including so-called low-carb diets $30-50 \%$ of energy), will be included, particularly in the reviewed meta-analyses.

\section{ARE ALL CALORIES EQUAL?}

The search for a diet that is more effective for weight control than simple calorie counting and willpower rests on the assumption that some nutrients and foods are more likely to produce a negative energy balance than others. Many scientists believe that a changed diet composition per se is an ineffective tool, that the individual must simply exert willpower to prevent overeating, and that we should be looking for alternative mechanisms for the physiological background of obesity, such as sedentary lifestyle, stress, shortened sleep, undesirable gut microbiota, genetics and so on. Some scientists do claim that all calories are equal, contradictory to the concept that some foods are more obesity promoting than others and that dietary recommendations and advice also aim to contribute to the prevention of weight gain and obesity. Evidence from observational studies shows that some dietary factors, such as sugar-rich soft drinks, refined high glycemic index $(\mathrm{HGl})$ carbohydrates, and energy-dense fat-rich fast foods, are associated with increased risk of weight gain and the development of overweight and obesity, whereas diet-sodas, whole grain and low glycemic index (LGI) carbohydrates may decrease risk. ${ }^{2}$ These observed associations have generally been confirmed by randomized controlled trials (RCT). The mechanisms responsible for an effect on energy balance are primarily promotion of an increased food intake, second, differences in effects on thermogenesis and resting energy expenditure and finally influence on energy absorption. There are various ways in which foods can increase caloric intake, including large portion sizes or hedonic qualities such as palatability, and their effects on hunger and satiety are very strong determinants and as such may be important targets for weight management. We believe that sugar-rich beverages, HGl foods and energy-dense foods consisting of mixtures of fats and refined carbohydrates, drive energy intake

${ }^{1}$ Department of Nutrition, Exercise and Sports, Faculty of Science, University of Copenhagen, Copenhagen, Denmark and ${ }^{2}$ Unit for Nutrition Research at the Central Kitchen (EFFECT), University of Copenhagen Hospital Herlev, Herlev, Denmark. Correspondence: Professor A Astrup, Department of Nutrition, Exercise and Sports, Faculty of Science, University of Copenhagen, Rolighedsvej 26, DK-1958 Frederiksberg, Denmark.

E-mail: ast@nexs.ku.dk

This paper is based on a presentation in a debate session that was held at the International Congress on Nutrition 2013, Spain.

Received 1 July 2014; revised 18 September 2014; accepted 24 September 2014; accepted article preview online 26 December 2014 ; advance online publication, 20 January 2015 
up through their low effect on satiety for the given caloric content The question is, to what extent can changes in these factors protect against overeating and weight gain in susceptible individuals if they eat a diet of optimal composition?

\section{LIMITATIONS OF DIFFERENT STUDY DESIGNS}

All types of studies and study designs in the evidence-based hierarchy have limitations, and we must collect the evidence from all lines of studies - animal studies, experimental and mechanistic studies, observational studies and randomized, controlled trials, in combination with genetic, epigenetic and omics technics-to understand differences in individual responsiveness to diets. Quality assessment of trials should not use a simplistic measure such as participant retention as a marker of diet compliance and adherence. $^{2-3}$ The totality of evidence is required to form recommendations, as all studies have limitations.

It is difficult to get a true picture of dietary intakes that is representative for a diet varying over many years from longitudinal, observational studies linking dietary factors to subsequent weight gain. ${ }^{4}$ Few studies are designed to address this question, as they lack repetitive measurements of biological markers for nutrient and food intake, and do not have consecutive measurements of body fat and lean body mass. This is particularly important when addressing the role of protein in the diet for changes in body fat over years, given the marked age-related decline in lean body tissue and parallel increase in body fat that is not revealed by the measurement of body weight alone.

The best evidence is thought to be gained from randomized, double-blind, placebo controlled studies, but these cannot be fully implemented in dietary studies for several reasons. First, dietary manipulation of macronutrient composition and Gl cannot be made in blinded designs if real foods are used in a realistic setting over months to years. Both the investigator and the subject are aware of which diet has been allocated. Thus, the investigator's and environment's preferences and beliefs potentially influence the participant. Even if the investigator is open and unbiased, commonly held public preconceptions may have a marked influence. $^{5}$ Second, it is impossible to achieve $100 \%$ adherence to diet composition over 6-12 months. Even the supermarket methodology that provides the subjects with all foods free of charge for several months does not guarantee strict adherence. ${ }^{6-7}$ Subjects enroled in an RCT with the prospect of eating the same diet every day for 6-12 months without any deviation cannot be expected to maintain high adherence. It is also important to realise that diet adherence cannot be assessed simply by looking at participant retention in a trial. ${ }^{3-4,7}$ We believe the scientific community has too readily ignored this. It is the rule rather than the exception that dietary compliance is monitored by dietary records made by the experimental subjects. Such records are prone to severe misreporting, in that subjects may report what they think the scientist would like to see. There is an obvious need for objective markers of intake of nutrients and specific foods, and rapid progress is fortunately being made in this area.

\section{CALORIE RESTRICTED OR AD LIBITUM DIETS?}

If the aim of a study is to examine whether calories from different macronutrients exert different impacts on energy balance, then the study design must allow for the influence of effects of appetite sensations on caloric intake. Allowances for changes in energy intake due to differences in effects on hunger, satiety and fullness, must be made using the ad libitum design, ${ }^{8-9}$ which also provides a much more pragmatic approach towards weight loss interventions. This is a priori excluded if a hypocaloric intake is prescribed. Moreover, no conclusions about any macronutrient-specific effects can be drawn if the biological marker of intake shows no meaningful difference between groups at the end of the intervention.

\section{EFFECTS OF PROTEIN ON SATIETY AND THERMOGENESIS}

The mechanisms by which higher protein intake may promote a negative fat balance and reduction of body fat stores are well established in short-term studies. The literature quite consistently reports that the thermic effect of protein is greater than that of carbohydrate or fat. Furthermore, there may be indications that animal protein has a greater effect than that of vegetable protein owing to differences in amino-acid composition, ${ }^{10}$ but this is still to be confirmed. Moreover, protein generally exerts a greater satiety effect than the other macronutrients, ${ }^{11-12}$ no matter whether the protein is in drinks or in solid foods. There is accumulating evidence that the satiety effect of protein is partly mediated by a synergistic effect of the satiety hormones GLP-1 and PYY released from the small intestine. ${ }^{11-13}$

During weight loss higher protein diets preserve lean body tissue, the major determinant of resting and 24-h energy expenditure, which in turn prevents an excessive reduction in energy expenditure. ${ }^{14}$ This is particularly significant when higher protein diets are used in combination with physical training.

\section{THE DIOGENES RANDOMIZED CONTROLLED TRIAL}

The DioGenes study is a pan-European, randomized, controlled multicenter trial that investigated dietary means of preventing weight (re)gain following weight loss in free-living conditions. ${ }^{8-9,15}$ In this trial a 6-month dietary intervention tested the effect of ad libitum diets, varying in dietary protein and $\mathrm{Gl}$, on weight maintenance and obesity-related risk factors, after an initial 8-week low-calorie diet (LCD) using meal replacements to induce a major weight loss before the ad libitum diets were introduced.

\section{Design, methodology and diets}

Families with at least one overweight or obese (body mass index: $27-45 \mathrm{~kg} \mathrm{~m}^{-2}$ ) parent, aged $18-65$ years and at least one child aged between 5 and 18 years, were enroled from eight European cities in 2005-2007. Details of recruitment, inclusion and exclusion criteria, design and study procedures have previously been described in detail. $^{8,9,15}$ In brief, eligible obese adults entered an 8-week $800 \mathrm{kcal}$ per day LCD period, with an aim to obtaining a minimum weight loss of $8 \%$. Families with at least one overweight/obese parent who achieved the $\geqslant 8 \%$ weight loss were subsequently randomized to one of five energy ad libitum diets. In Maastricht and Copenhagen, the families were provided with all foods free of charge from a university supermarket for 6 months, whereas the other six centres provided the families with careful instruction.

Trained dieticians gave detailed instructions on the ad libitum diets, which differed in protein content and Gl: normal-protein (NP)/LGl; NP/HGl; high-protein (HP)/LGl; HP/HGl; and control diet with medium protein content and no specific instructions on $\mathrm{Gl}^{8}$ All diets were moderate in fat (25-30\% of energy). The target was for $10-15 \%$ of energy intake to be comprised of protein in the normal-protein (NP) and $23-28 \%$ in the HP groups (thus a difference between the HP and NP groups of $12 \%$ of energy). Participants in the LGl groups were advised to consume LGI foods and those in the HGI groups HGI foods within a food group. ${ }^{8}$ The aim was to achieve a 15-point $\mathrm{Gl}$ difference between the $\mathrm{HGl}$ and LGI groups (Table 1). During the 6-month intervention, participants were requested to attend six counselling sessions, during which intensive guidance was provided. Participants were advised to maintain their achieved weight loss during the intervention period, but further weight loss was also allowed.

\section{RESULTS}

Diet compliance

A total of 932 adults started the 8-week LCD period and 773 adults from 634 families started the 6-month intervention period. ${ }^{15}$ 
The HP diet groups consumed $5.4 \%$ points more energy from protein than the NP groups, and the HGI diet groups achieved 5.1 higher $\mathrm{Gl}$ than the LGl groups.

Effects on body weight and body fat

The mean 8-week weight loss with the LCD was $11.0 \mathrm{~kg}$. As a reflection of differential success with the subsequent ad libitum diets, fewer adults in the HP and the LGI groups than in the NP$\mathrm{HGl}$ group dropped out of the trial $(25-26 \%$ vs $37.4 \%$; $P<0.02){ }^{15}$ Only the NP-HGl diet caused significant subsequent weight regain $(1.67 \mathrm{~kg})$. Weight regain was $0.93 \mathrm{~kg}$ less in the HP groups than in the NP group ( $P=0.003)$, and $0.95 \mathrm{~kg}$ less in the $\mathrm{LGl}$ groups than in the HGl groups $(P=0.003$, see Figure 1$)$. Different sensitivity analyses provided similar and consistent results. ${ }^{15}$ The HP diets were more likely to produce an additional $5 \%$ weight loss after randomisation than were the NP diets $(\mathrm{OR}, 1.92 ; P=0.03)$, and the LGI diets were more likely to result in an additional $5 \%$ weight loss than were the $\mathrm{HGI}$ diets $(\mathrm{OR}, 2.54 ; P=0.003)$. In conclusion, a slight increase in dietary protein and corresponding reduction in carbohydrate, together with lowering the $\mathrm{Gl}$ of the diet by 8 units, exerted an additive effect on body weight regulation, so the combination was effective in preventing any weight regain

Table 1. Mean acceptability scores (confidence intervals) and $P$-values for comparing different subsets of intervention diets (ITT analysis)

\begin{tabular}{lccl}
\hline & $\begin{array}{c}\text { Normal protein } \\
(\mathrm{n}=253)\end{array}$ & $\begin{array}{c}\text { Higher Protein } \\
(\mathrm{n}=275)\end{array}$ & P-value \\
\hline Satisfied & $62.7(60.4,65.1)$ & $65.7(63.4,67.9)$ & 0.09 \\
Convenient & $58.7(56.4,61.0)$ & $63.3(61.1,65.5)$ & 0.004 \\
Easy & $49.9(47.4,52.5)$ & $55.4(53.0,57.8)$ & 0.002 \\
Motivated & $69.6(67.3,71.8)$ & $72.6(70.5,74.8)$ & 0.05 \\
Enjoyable & $56.9(54.5,59.3)$ & $62.0(59.7,64.3)$ & 0.002 \\
\hline
\end{tabular}

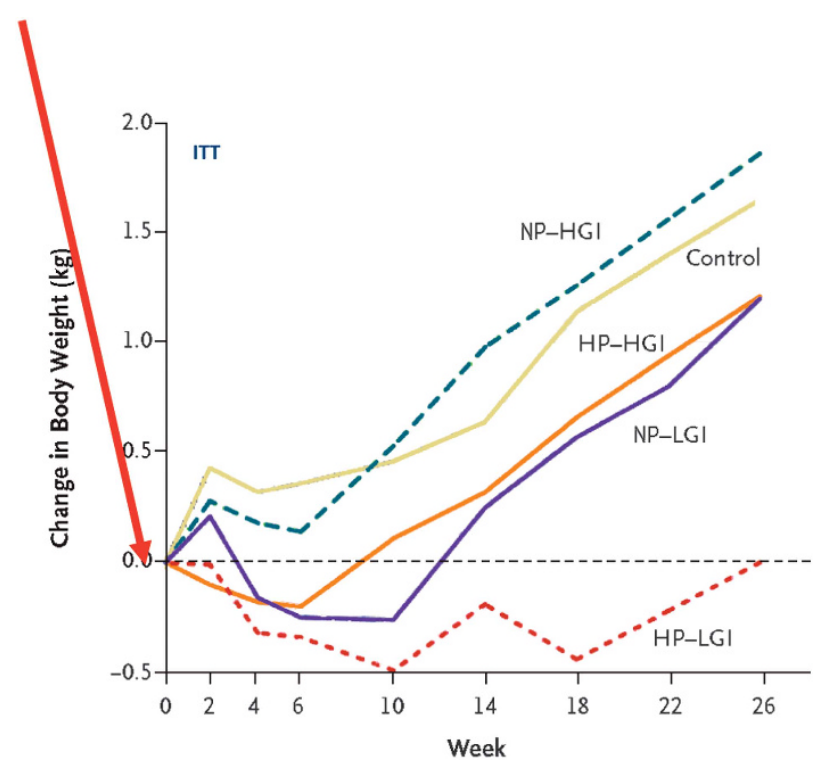

Figure 1. After an $\sim 11 \mathrm{~kg}$ weight loss among the adult obese parents achieved by a 8 -week $800 \mathrm{kcal} /$ day diet, the entire family was randomized to different ad libitum diets with either low or high glycemic index ( $\mathrm{LGl}$ or $\mathrm{HGl})$, in combination with either normal or high protein (NP or HP). Both LGI and HP reduced weight regain significantly, and the combination of LGI and HP exerted an additive effect that completely prevented weight regain during the 6 months following the initial weight loss. The overweight and obese children in the LGI-HP group lost body fat spontaneously without adverse effect of growth or risk factors. for 6 months following a $10 \mathrm{~kg}$ weight loss, and also in reducing drop-out rate.

\section{Long-term effects}

In the two supermarket centres the intervention consisted of 2 month LCD, 6 months with free foods from the supermarket, and an additional 6 months with dietetic instruction. The third part of the study enabled us to assess the longer-term effects of the diets, although in a smaller cohort. ${ }^{16}$ The 256 adults who completed the 2 month LCD lost $11.2 \mathrm{~kg}$ and the mean weight regain over the 12 -month intervention period for entire group was $3.9 \mathrm{~kg}(95 \% \mathrm{Cl}$ 3.0 to 4.8 ). Subjects on the HP diets regained $2.0 \mathrm{~kg}$ less than the NP group in completer analysis $(P=0.017)$, and $2.8 \mathrm{~kg}(P<0.001)$ in the ITT analysis. No consistent effect of $\mathrm{Gl}$ on weight regain was found. For the entire 14-month intervention those on the higher protein diets lost a total of $7.3 \mathrm{~kg}$ compared with $4.5 \mathrm{~kg}$ in the NP groups. $^{16}$

The higher protein groups also regained $1.6 \mathrm{~kg}$ less-fat mass $(P=0.043)$ and $0.9 \mathrm{~cm}$ less in sagittal diameter compared with the NP groups $(P=0.012)$. These effects were achieved by reported differences in protein intake between the NP and HP groups of only $7 \%$ of energy.

Diet effects on body fatness and health in children

The 827 children aged 5-18 years only participated in the randomized part of the trial, and 465 children (58\%) completed all assessments, including measurements of body composition. ${ }^{17}$ Among these children only small changes in diet composition were achieved; that is, the difference in $\mathrm{Gl}$ was $2.3 \mathrm{Gl}$ units, and in protein $4.9 \mathrm{E} \%$ points. The $\mathrm{NP} / \mathrm{HGl}$ diet increased body fat mass more than the other diets, and the HP/LGI diet produced a spontaneous decline in the prevalence of overweight and obesity of $14.3 \%(P=0.03) .{ }^{17}$ In a smaller cohort of the children $(n=253)$, we obtained a complete set of anthropometry and dietary data and blood variables, and here we found that after 6 months the HP diets had significantly reduced waist circumference by $2.7 \mathrm{~cm}$ and LDL-cholesterol by $0.25 \mathrm{mmolI}^{-1}$ compared with the NP diets. ${ }^{18}$ In the supermarket centres, with better diet adherence, the HP diet produced a reduction in waist circumference of $3.1 \mathrm{~cm}$ more than NP diets $(P=0.004)$, and reductions of $1.0 \mathrm{~mm} \mathrm{Hg}$ $(P<0.01)$ in diastolic blood pressure (BP), $6.5 \mathrm{~mm} \mathrm{Hg}(P<0.02)$ in MAP, 6 pmol I $^{-1}(P<0.02)$ in serum insulin and 0.8 points $(P<0.02)$ in HOMA-IR.

There were no adverse effects of the HP diet on bone health in the children. ${ }^{19}$

\section{Effects on risk factors for cardiovascular disease (CVD) and diabetes}

The initial weight loss of around $11 \mathrm{~kg}$ obviously had beneficial effects on diabetes and CVD risk factors, though the obese participants were generally free of apparent diabetes and CVD. ${ }^{15}$ However, this initial weight loss clearly makes it more difficult to detect further beneficial effects on blood lipids related to the subsequent divergence in body weight and fat on the different diets. The initial $11.2 \mathrm{~kg}$ weight loss had statistically and clinically significant effects on important CVD risk factors. The weight loss reduced high-sensitivity C-reactive protein by nearly $40 \%$ $(-1.15 \mathrm{mg} / \mathrm{l} ; P<0.001)$, and also low- and high-density lipoprotein cholesterol, triglycerides and $\mathrm{BP}^{20}$ During the subsequent 6-month diet more marked decreases in high-sensitivity C-reactive protein blood levels $(0.46 \mathrm{mg} / \mathrm{l})$ were found in the groups assigned to low-glycemic-index diets than in those on $\mathrm{HGl}$ diets $(P<0.001){ }^{20}$ Groups on normal-protein diets had a $0.25 \mathrm{mg} / \mathrm{l}$ greater reduction in high-sensitivity $C$-reactive protein than those on HP diets $(P<0.001)$. Overall, the HP-LGl diet exerted a beneficial effect on low-grade inflammatory status, and the 
findings of the effect of the LGl diets confirm reports from observational studies.

The effect on BP was studied by Enqberink et al., ${ }^{21}$ and they found that the protein component of the diet in particular exerted an effect on this risk factor. Systolic BP during the 6-month dietary intervention increased in both treatment groups, but it was $2.2 \mathrm{~mm} \mathrm{Hg}$ less (95\% Cl: -4.6 to $0.2 \mathrm{~mm} \mathrm{Hg}, P=0.08$ ) in the HP group than in the lower protein control group. In the 191 (pre) hypertensive subjects, the HP diets exerted a greater effect compared with the NP diets $(-4.2 \mathrm{~mm} \mathrm{Hg}, P=0.02) .{ }^{21}$ The effect was attenuated after adjustment for initial BP $(-3.4 \mathrm{~mm} \mathrm{Hg}$, $P=0.048)$ and after additional adjustment for weight change $(-2.7 \mathrm{~mm} \mathrm{Hg}, P=0.11)$. Diastolic BP showed similar results. These findings suggest that a BP reduction after weight loss is better maintained when the intake of protein is increased at the expense of carbohydrates. This effect is only partly mediated by body weight.

The effect on diabetes risk was analysed by Goyenechea et al. ${ }^{22}$ The NP-HGl diet induced a higher insulin resistance (HOMA-IR) during the 6 months period as compared with the control. By contrast, the insulin response was lower in the HP-LGI diet after 60 and $90 \mathrm{~min}$ of an Oral Glucose Tolerance test conducted after the 6-month intervention. The two LGI diets (either with HP or NP content) also led to a decrease in fructosamine levels during the trial. $^{22}$

Finally, the effect of the diets on the metabolic syndrome (MS) was assessed by Papadaki et al. ${ }^{23}$ As expected, the initial 8-week weight loss reduced the prevalence of MS (33.9\% vs $15.9 \%$; $P<0.001)$ and MS score $(-1.48$ vs $-4.45 ; P<0.001)$. The subsequent 6-month diets had significant effects on MS score, with the highest increase detected in the NP-HGI group.

\section{Importance of genetic make-up}

The DioGenes trial has also been used to look for obesity genes, and it has been found that SNP-diet interactions on weight, waist and fat mass regain suggest that genetic variation in nutrient sensitive genes can modify the response to diet. ${ }^{24}$ More importantly, we found that a genetic variant in the rs987237 gene was strongly associated with the effectiveness of the higher protein diet. The higher protein diets were beneficial for weight maintenance in the AA genotype group ( $67 \%$ of participants), but in the AG and GG groups (33\%) no differences between the effect on weight gain of the normal and higher protein diets were found. ${ }^{25}$ On the HP diet carriers of the obesity risk allele ( $\mathrm{G}$ allele) regained $1.84 \mathrm{~kg}(95 \% \mathrm{Cl}: 0.02 ; 3.67, P=0.047)$ more body weight per risk allele than individuals on a NP diet.

TFAP2B rs987237 and dietary protein/carbohydrate interacted to modify weight maintenance. Considering the carbohydrate proportion of the diet, the interaction was different from the previously reported rs987237-fat-to-carbohydrate ratio interaction for weight loss. Thus, TFAP2B-macronutrient interactions might diverge depending on the nutritional state. ${ }^{25}$ The findings need replication, but if confirmed in other trials they will be important for personalised nutrition advice. It is obvious that there might be individual differences that determine whether a diet is ineffective for weight control in all individuals.

The macronutrient composition of the diet may also interact with genes to determine the effect on blood lipids. In the DioGenes trial we found that after adjusting for multiple testing, an SNP dietary protein interaction effect on TAG was identified for lipin 1 (LPIN1) rs4315495, with a decrease in TAG of $0.26 \mathrm{mmoll}^{-1}$ per A-allele per protein unit $(P<0.00004){ }^{26}$

\section{DISCUSSION}

The most significant outcome of the DioGenes study was that very subtle changes in diet composition with respect to protein and carbohydrates seem to have a major impact on spontaneous caloric intake during $a b$ libitum conditions that mimic real life, and hence improve obese subjects' ability to maintain a rapid $10-\mathrm{kg}$ weight loss. The changes in protein to carbohydrate ratio and the reduction in $\mathrm{Gl}$ had additive effects on weight control, but exerted differential effects of various risk factors of CVD and diabetes. The impact of the diet was remarkable among the children: the overweight and obese children started to lose weight spontaneously; and also experienced improvements in various risk factors very consistent with the improvements observed in their parents.

It was also evident that the acceptability of the diet was very high and that it was easily incorporated into a normal food culture. $^{27}$ This was supported by the findings that the higher protein diets were more acceptable than the normal protein diets, whereas no differences between the HGI vs LGI diets were found concerning acceptability and tolerability ${ }^{24}$ (Table 1 ). The observation that the drop-out rate was significantly lower in the higher protein and LGI diet groups would normally be attributed to the greater weight loss and maintenance of success, but it also indicates that the diets were easily incorporated into a normal food culture, and that availability, cost and taste were not barriers for adopting the changed food habits. The lower efficacy of the LGI diets after 1 year is very probably owing to the poor availability of Gl-labelled foods, and lack of information and emphasis on $\mathrm{Gl}$, in most European countries.

Although the studies and analyses based on the DioGenes study clearly show that the higher protein, LGI diet is superior to the conventional low-fat high-carb diet, the genetic analyses also suggest that the effect is particularly marked and robust among $2 / 3$ of the population with a certain genetic make-up, whereas the protein to carbohydrate ratio is immaterial for weight control in the last $1 / 3$ of the population. The genetic variant in the rs987237 gene seems to determine the effectiveness of the higher protein diet, that is, the higher protein diets were beneficial for weight maintenance in the AA genotype group ( $67 \%$ of participants). If replicated in other studies, this finding opens up for a more personalised nutrition based on gene-nutrient interactions. However, no adverse effects have been found so these findings do not preclude recommending this diet composition for all individuals with overweight problems.

There are many ongoing studies designed to elucidate the mechanisms by which protein and LGI carbohydrates exert their effects on appetite regulation, and studies point at enhanced satiety mediated by GLP-1, PYY and perhaps CCK. ${ }^{11}$ Differential effects of various protein sources have also been studied in DioGenes. ${ }^{9-28}$ Various omics techniques have been applied in the ${ }^{29}$ DioGenes study to search for predictors of weight loss and weight regain ${ }^{30-34}$ and these analyses may lead to a better understanding of the inter-individual responsiveness to diets.

Meta-analyses of efficacy of higher protein diets

A number of other studies demonstrating the importance of higher protein, lower carbohydrate load and lower Gl of carbohydrates, for weight control and comorbid conditions support the generalisability of the DioGenes diet. ${ }^{35-36}$ It is beyond the scope of this paper to review these studies, but a number of meta-analyses have clearly shown the value of higher protein, reduced carbohydrate diets and recent long-term evidence also supports that even a small change in protein to carbohydrate makes a difference for weight control. ${ }^{37}$

Dissemination of results to the overweight population It is evident that even the publication of the all the results of the DioGenes trial in New England Journal of Medicine does not communicate the usefulness of the diet to the overweight population, which is in fact one of the goals of the EU funding 
of research. We therefore conducted a translational project to explain the dietary principles of the DioGenes diet in popular diet and cook books. To date the books have been published in Danish, Norwegian, Dutch, Spanish and English (Figure 2).

\section{ONGOING AND FUTURE RESEARCH}

The role of the DioGenes diet for disease prevention

Prevention of type 2 diabetes (T2D). The DioGenes diet showed beneficial effects on body weight regulation, glucose metabolism and inflammatory markers. However, previous large diabetes prevention studies have found that weight loss produced by the traditional recommended diet, with normal protein and without emphasis on $\mathrm{Gl}$, prevents $\mathrm{T} 2 \mathrm{D}$ in prediabetic individuals. In neither of these studies, however, was the quality of the recommended dietary intake of macronutrients (for example, protein or carbohydrate) in focus. In continuation of the DioGenes study, we decided to investigate if a HP, LGI diet would be more beneficial with regards to preventing T2D in prediabetic individuals compared with the currently recommended diet (less protein, slightly higher Gl). The project 'PREVIEW'38 (PREVention of diabetes through lifestyle Intervention and population studies in Europe and around the World) (www.previewstudy.com) involves two lines of evidence: (1) a 3-year RCT in up to 2500 individuals; and (2) data analyses from large cohort studies. The overall goal of the PREVIEW project is to identify the most successful combination of both diet and physical activity to prevent the incidence of T2D in a large sample of

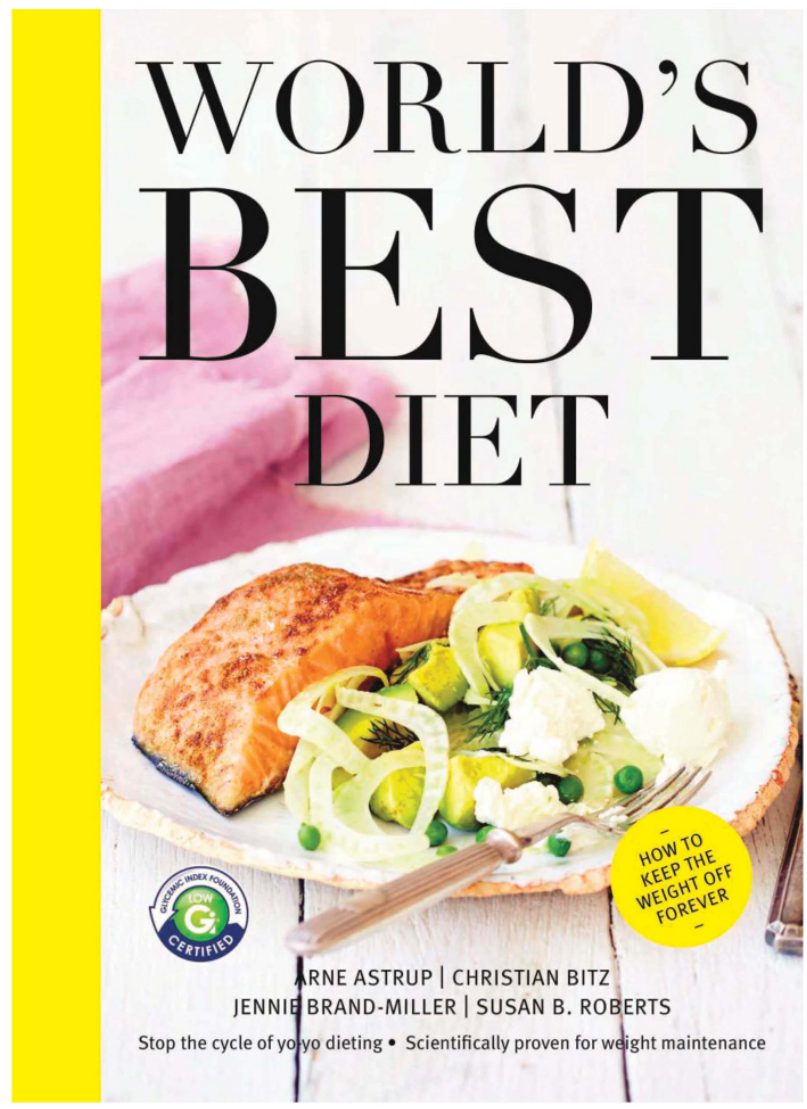

Figure 2. The results from the DioGenes randomized trial have been translated into popular books that, in an educational way, explain how a slight increase in dietary protein and corresponding reduction in total carbohydrates, plus focus on LGI carbohydrates, help weight loss and maintenance. This book has been published in Danish, Norwegian, Dutch, Spanish and in September 2014 in English. prediabetic, overweight or obese people around the world. It includes 15 partners from a total of 11 countries, 8 in Europe (FIN, DK, BG, ES, NL, UK, DE and Switzerland) and 3 in non-European countries (Canada, New Zealand and Australia).

Programming of the foetus to a healthy body weight and composition. There is increasing circumstantial evidence from observational studies that suggests that a too low protein content and too high carbohydrate content of the diet is responsible for excessive weight gain among pregnant women. This excessive weight gain has per se adverse effects on mothers' health and it is also seen to adversely affect the foetus, but the diet composition may also determine body composition of the foetus and exert a programming effect that permanently makes the offspring prone to overweight and obesity, and related disorders. A high maternal dietary protein to carbohydrate ratio is associated with a larger lean body mass and lower fat mass of the foetus and child. This suggests that a maternal diet with a lower protein and higher carbohydrate content is increasing the risk of excessive gestational weight gain and risk of (sarcopenic) obesity in the offspring. Most of the evidence, however, is derived from observational studies and there is a risk that these associations are not causal, but owing to confounding. APPROACH is a randomized dietary trial that investigates how the DioGenes diet during pregnancy influences the programming of the offspring. This study will improve our understanding of how the DioGenes diet can influence body weight during pregnancy and impact on growth and development of the offspring, both during the foetal stage and until 9 years of age, including risk markers for later development of metabolic diseases, especially diabetes and MS.

\section{CONFLICT OF INTEREST}

AA acts as consultant or member of advisory boards for The Global Dairy Platform, USA; McCain, USA; Pathway Genomics, USA; Dutch Beer Knowledge Institute, Netherlands; McCain, USA; McDonalds, USA. The remaining authors declare no conflict of interest.

\section{REFERENCES}

1 Paddon-Jones D, Westman E, Mattes RD, Wolfe RR, Astrup A, Westerterp-Plantenga M. Protein, weight management, and satiety. Am J Clin Nutr 2008; 87: 1558S-1561S.

2 Astrup A. Yogurt and dairy product consumption to prevent cardiometabolic diseases: epidemiologic and experimental studies. Am J Clin Nutr 2014; 99: 1235S-1242S.

3 Astrup A, Brand-Miller J. Obesity: have new guidelines overlooked the role of diet composition? News and views. Nat Rev Endocrinol 2014; 10: 132-133.

4 Astrup A, Brand-Miller J. Reply: totality of evidence needed for nutrition recommendations. Nat Rev Endocrinol 2014; 10: 310.

5 Casazza K, Fontaine KR, Astrup A, Birch LL, Brown AW, Bohan Brown MM et al. Myths, presumptions, and facts about obesity. N Engl J Med 2013; 368: 446-454.

6 Skov AR, Toubro S, Raben A, Astrup A. A method to achieve control of dietary macronutrient composition in ad libitum diets consumed by free-living subjects. Eur J Clin Nutr 1997; 51: 667-672.

7 Astrup A, Geiker NR. Efficacy of higher protein diets for long-term weight control. How to assess quality of randomized controlled trials? Nutr Metab Cardiovasc Dis 2014; 24: 220-223.

8 Moore CS, Lindroos AK, Kreutzer M, Larsen TM, Astrup A, van Baak MA et al. Diogenes. Dietary strategy to manipulate ad libitum macronutrient intake, and glycaemic index, across eight European countries in the Diogenes Study. Obes Rev 2010; 11: 67-75.

9 Larsen TM, Dalskov S, van Baak M, Jebb S, Kafatos A, Pfeiffer A et al. The Diet, Obesity and Genes (Diogenes) Dietary Study in eight European countries a comprehensive design for long-term intervention. Obes Rev 2010; 11: 76-91.

10 Mikkelsen PB, Toubro S, Astrup A. The effect of fat-reduced diets on 24-h energy expenditure: comparisons between animal protein, vegetable protein, and carbohydrate. Am J Clin Nutr 2000; 72: 1135-1141.

11 Belza A, Ritz C, Sørensen MQ, Holst JJ, Rehfeld JF, Astrup A. Contribution of gastroenteropancreatic appetite hormones to protein-induced satiety. Am J Clin Nutr 2013; 97: 980-989.

12 Maersk M, Belza A, Holst JJ, Fenger-Grøn M, Pedersen SB, Astrup A et al. Satiety scores and satiety hormone response after sucrose-sweetened soft drink 
compared with isocaloric semi-skimmed milk and with non-caloric soft drink: a controlled trial. Eur J Clin Nutr 2012; 66: 523-529.

13 Schmidt JB, Gregersen NT, Pedersen SD, Arentoft JL, Ritz C, Schwartz TW et al. Effects of PYY3-36 and GLP-1 on energy intake, energy expenditure, and appetite in overweight men. Am J Physiol Endocrinol Metab 2014; 306: E1248-E1256.

14 Wycherley TP, Moran LJ, Clifton PM, Noakes M, Brinkworth GD. Effects of energyrestricted high-protein, low-fat compared with standard-protein, low-fat diets: a meta-analysis of randomized controlled trials. Am J Clin Nutr 2012; 96: 1281-1298.

15 Larsen TM, Dalskov SM, van Baak M, Jebb SA, Papadaki A, Pfeiffer AF et al. Diet, Obesity, and Genes (Diogenes) Project. Diets with high or low protein content and glycemic index for weight-loss maintenance. N Engl J Med 2010; 363: 2102-2113.

16 Aller EE, Larsen TM, Claus H, Lindroos AK, Kafatos A, Pfeiffer A et al. Weight loss maintenance in overweight subjects on ad libitum diets with high or low protein content and glycemic index: the DIOGENES trial 12-month results. Int J Obes 2014; 38: 1511-1517.

17 Papadaki A, Linardakis M, Larsen TM, van Baak MA, Lindroos AK, Pfeiffer AF et al. The effect of protein and glycemic index on children's body composition: the DiOGenes randomized study. Pediatrics 2010; 126: e1143-e1152.

18 Damsgaard CT, Papadaki A, Jensen SM, Ritz C, Dalskov SM, Hlavaty P et al. Higher protein diets consumed ad libitum improve cardiovascular risk markers in children of overweight parents from eight European countries. J Nutr 2013; 143 810-817.

19 Dalskov SM, Müller M, Ritz C, Damsgaard CT, Papadaki A, Saris WH et al. Effects of dietary protein and glycaemic index on biomarkers of bone turnover in children. Br J Nutr 2014; 111: 1253-1262.

20 Gögebakan O, Kohl A, Osterhoff MA, van Baak MA, Jebb SA, Papadaki A et al. Effects of weight loss and long-term weight maintenance with diets varying in protein and glycemic index on cardiovascular risk factors: the diet, obesity, and genes (DiOGenes) study: a randomized, controlled trial. Circulation 2011; 124 2829-2838.

21 Engberink MF, Geleijnse JM, Bakker SJ, Larsen TM, Handjieva-Darlesnka T, Kafatos $A$ et al. Effect of a high-protein diet on maintenance of blood pressure levels achieved after initial weight loss: the DiOGenes randomized study. J Hum Hypertens 2014; 29: 58-63.

22 Goyenechea E, Holst C, Saris WH, Jebb S, Kafatos A, Pfeiffer A et al. Effects of different protein content and glycemic index of ad libitum diets on diabetes risk factors in overweight adults: the DIOGenes multicentre, randomised, dietary intervention trial. Diabetes Metab Res Rev 2011; 27: 705-716.

23 Papadaki A, Linardakis M, Plada M, Larsen TM, Damsgaard CT, van Baak MA et al. Impact of weight loss and maintenance with ad libitum diets varying in protein and glycemic index content on metabolic syndrome. Nutrition 2014; 30: 410-417.

24 Larsen LH, Angquist L, Vimaleswaran KS, Hager J, Viguerie N, Loos RJ et al. Analyses of single nucleotide polymorphisms in selected nutrient-sensitive genes in weight-regain prevention: the DIOGENES study. Am J Clin Nutr 2012; 95: $1254-1260$

25 Stocks T, Ängquist L, Hager J, Charon C, Holst C, Martinez JA et al. TFAP2B -dietary protein and glycemic index interactions and weight maintenance after weight loss in the DiOGenes trial. Hum Hered 2013; 75: 213-219.

26 Brahe LK, Ängquist L, Larsen LH, Vimaleswaran KS, Hager J, Viguerie N et al. Influence of SNPs in nutrient-sensitive candidate genes and gene-die interactions on blood lipids: the DiOGenes study. Br J Nutr 2013; 110: 790-796.
27 McConnon A, Horgan GW, Lawton C, Stubbs J, Shepherd R, Astrup A et al. Experience and acceptability of diets of varying protein content and glycemic index in an obese cohort: results from the Diogenes trial. Eur J Clin Nutr 2013; 67: 990-995.

28 Bendtsen LQ, Lorenzen JK, Larsen TM, van Baak M, Papadaki A, Martinez JA et al. Associations between dairy protein intake and body weight and risk markers of diabetes and CVD during weight maintenance. Br J Nutr 2014; 111: 944-953.

29 Bendtsen LQ, Lorenzen JK, Bendsen NT, Rasmussen C, Astrup A. Effect of dairy proteins on appetite, energy expenditure, body weight, and composition: a review of the evidence from controlled clinical trials. Adv Nutr 2013; 4 418-438.

30 Wang P, Menheere PP, Astrup A, Andersen MR, van Baak MA, Larsen TM et al. Metabolic syndrome, circulating RBP4, testosterone, and SHBG predict weight regain at 6 months after weight loss in men. Obesity 2013; 21: 1997-2006.

31 Wang P, Holst C, Astrup A, Bouwman FG, van Otterdijk S, Wodzig WK et al. Blood profiling of proteins and steroids during weight maintenance with manipulation of dietary protein level and glycaemic index. Br J Nutr 2012; 107: 106-119.

32 Kunešová $M$, Hlavatý $P$, Tvrzická $E$, Staňková $B$, Kalousková $P$, Viguerie $N$ et al. Fatty acid composition of adipose tissue triglycerides after weight loss and weight maintenance: the DIOGENES study. Physiol Res 2012; 61: 597-607.

33 Rubio-Aliaga I, Marvin-Guy LF, Wang P, Wagniere S, Mansourian R, Fuerholz A et al. Mechanisms of weight maintenance under high- and low-protein, low-glycaemic index diets. Mol Nutr Food Res 2011; 55: 1603-1612.

34 Wang P, Holst C, Andersen MR, Astrup A, Bouwman FG, van Otterdijk S et al. Blood profile of proteins and steroid hormones predicts weight change after weight loss with interactions of dietary protein level and glycemic index. PLoS One 2011; 6 : e16773 Erratum in: PLoS One 2011; 6

35 Santos SL, Esteves SS, da Costa Pereira A, Yancy Jr WS, Nunes PL. Systematic review and meta-analysis of clinical trials of the effects of low carbohydrate diets on cardiovascular risk factors. Obes Rev 2012; 13: 1048-1066.

36 Krieger JW, Sitren HS, Daniels MJ, Langkamp-Henken B. Effects of variation in protein and carbohydrate intake on body mass and composition during energy restriction: a meta-regression. Am J Clin Nutr 2006; 83: 260-274.

37 Clifton PM, Condo D, Keogh JB. Long term weight maintenance after advice to consume low carbohydrate, higher protein diets - a systematic review and meta analysis. Nutr Metab Cardiovasc Dis 2014; 24: 224-235.

38 Raben A, Fogelholm M, Feskens E, Westerterp-Plantenga $M$, Schlicht W, Brand-Miller J. PREVIEW: PREVention of diabetes through lifestyle Intervention and population studies in Europe and around the World. On behalf of the PREVIEW consortium. Obes Facts 2013; 6: 194.

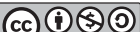

This work is licensed under a Creative Commons AttributionNonCommercial-ShareAlike 4.0 International License. The images or other third party material in this article are included in the article's Creative Commons license, unless indicated otherwise in the credit line; if the material is not included under the Creative Commons license, users will need to obtain permission from the license holder to reproduce the material. To view a copy of this license, visit http:// creativecommons.org/licenses/by-nc-sa/4.0/ 